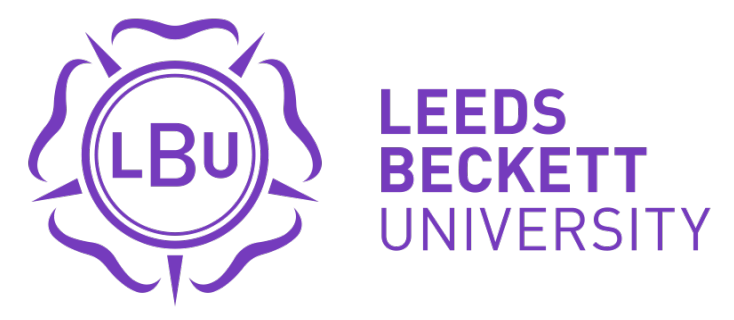

Citation:

Lugosi, P and Jameson, S (2017) Challenges in Hospitality Management Education: Perspectives from the United Kingdom. Journal of Hospitality and Tourism Management, 31. pp. 163-172. ISSN 1447-6770 DOI: https://doi.org/10.1016/j.jhtm.2016.12.001

Link to Leeds Beckett Repository record:

https://eprints.leedsbeckett.ac.uk/id/eprint/3440/

Document Version:

Article (Accepted Version)

Creative Commons: Attribution-Noncommercial-No Derivative Works 4.0

The aim of the Leeds Beckett Repository is to provide open access to our research, as required by funder policies and permitted by publishers and copyright law.

The Leeds Beckett repository holds a wide range of publications, each of which has been checked for copyright and the relevant embargo period has been applied by the Research Services team.

We operate on a standard take-down policy. If you are the author or publisher of an output and you would like it removed from the repository, please contact us and we will investigate on a case-by-case basis.

Each thesis in the repository has been cleared where necessary by the author for third party copyright. If you would like a thesis to be removed from the repository or believe there is an issue with copyright, please contact us on openaccess@leedsbeckett.ac.uk and we will investigate on a case-by-case basis. 


\title{
Challenges in Hospitality Management Education: Perspectives from the United Kingdom
}

\author{
Peter Lugosi \\ Oxford School of Hospitality Management \\ Oxford Brookes University \\ plugosi@brookes.ac.uk \\ Stephanie Jameson \\ School of Events, Tourism and Hospitality \\ Leeds Beckett University
}

Published as: Lugosi, P. and Jameson, S. (2017) Challenges in hospitality management education: Perspectives from the United Kingdom. Journal of Hospitality and Tourism Management, 31, pp. 163-172, DOI: 10.1016/j.jhtm.2016.12.001.

\begin{abstract}
Drawing on qualitative data gathered from educators based in the United Kingdom, this paper examines their perceptions of significant challenges facing contemporary hospitality management education. These include: engaging contemporary students, particularly through new technologies; the growing presence of international students; institutional constraints, resource pressures and the distinctiveness of hospitality management education; ongoing tensions between hospitality's intellectual development and its practice focus; and new course designs, delivery models and partnerships. The study also explores their views on how those are likely to evolve in the future. The findings suggest that many of the key challenges are not unique to the hospitality management area, but they also highlight many pressing concerns specific to this sector. Importantly, the findings help to identify how individuals and institutions are responding to particular challenges in higher education.
\end{abstract}

Keywords: Higher Education Academy; Hospitality; Learning; Teaching; Challenges; Future

\section{Highlights}

Explores challenges in supporting contemporary students and international cohorts

Reflects on institutional constraints and the intensification of academic work

Examines the position of hospitality education within business schools and faculties

Highlights tensions between hospitality's intellectual growth and its practice focus

Considers impacts of new course designs, partnerships and models of delivery 


\section{Introduction}

Global financial instability and policy shifts have led to dramatic changes in the funding and management of higher education (Ayikoru, Tribe, \& Airey, 2009; Ball, 2012; Cheng, 2016; Dredge, Benckendorff, Day, Gross, Walo, Weeks, \& Whitelaw, 2013). The transformation of the international educational landscape has prompted growing questioning of how higher education (including research) operates in contemporary society more generally. These changes have also driven increasing critical debate on the current state and future prospects for hospitality management education (cf. Fullagar \& Wilson, 2012; Lugosi, Lynch, \& Morrison, 2009). However, the debate concerning contemporary hospitality management education has thus far been dominated by non-empirical discussion pieces. Whilst these have provided important reference points, they reflect the perspectives of specific authors (cf. Lashley, 2013; 2015; Wood, 2015). Empirical studies reflecting on the state of hospitality management education have provided descriptive overviews of the educational sector in the United Kingdom (UK) and Australia (HEFCE, 1998; Jameson, Walmsley, \& Ball, 2006; Robinson, Breakey, \& Craig-Smith, 2010); or they have focused on specific issues such as the role of practical training facilities (Alexander, 2007; Alexander, Lynch, \& Murray, 2009), the performance of hospitality in research assessment exercises (Litteljohn, 2004), and the state of publication in the hospitality field (Rivera \& Upchurch, 2008). There is a gap in knowledge regarding academics' views of the state of hospitality management education, particularly in the UK, where the higher education sector has undergone significant changes in the past decade. This paper thus builds on, and contributes to, existing knowledge by examining, in further detail, the perspectives of UK university educators on the current state and future challenges for hospitality management education and, importantly, on how individuals and institutions are choosing to interpret and respond to some of those challenges.

The origin of this paper was an initiative from the UK's Higher Education Academy (HEA) who were conducting research into the state of university-level learning and teaching in a wide range of subject disciplines in order to better understand the sector's needs. The HEA used the research to form a national strategy to support higher education pedagogy. This paper focuses on data related to hospitality management education, principally in the UK. However, the findings highlight themes and issues that emerge in other fields and disciplines, and they are also likely to chime with practitioners outside the UK (cf. Bulman, 2015). The findings of this paper can thus be used to develop more effective pedagogic practices to address challenges and ensure the sustainability of higher education provision within and beyond the hospitality field.

The paper begins with a short overview of the key literature, which has reflected on the past, present and future prospects for hospitality management education. The paper then introduces the methods before presenting and discussing seven key thematic areas emerging from the data: 1 . engaging the contemporary student; 2. international students; 3 . the impacts of emerging 'innovative' and 'efficient' course designs; 4 . institutional constraints and the intensification of academic work; 5 . the position of hospitality management within business schools and faculties; 6 . the 
ongoing tensions between academia and practice, particularly as hospitality seeks to develop as an academic field of enquiry whilst maintaining its professional relevance; and 7. the evolution of teaching in hospitality, with particular reference to new models of delivery and partnerships. The paper concludes by reflecting further on the key challenges identified through the primary research and upon the implications for the sector and its stakeholders.

\section{Perspectives on hospitality management education}

The last two decades has seen an increasing sense of self-awareness and reflection regarding the current state and the future evolution of hospitality (Jameson et al., 2006; Jones, 2004; Lugosi, 2009; Slattery, 2002; Lynch, Germann Molz, Mclntosh, Lugosi, \& Lashley 2011). Some have adopted an optimistic position on the intellectual development of the field, acknowledging the growing engagement with other disciplines and subject areas, which has enabled hospitality to open up new lines of enquiry and to export knowledge into other disciplines (Lashley, 2008; Lugosi et al., 2009; Morrison \& O'Gorman, 2008). In 2003, Morrison and O'Mahony suggested that: 'some management may be challenged, inherited rituals questioned, and breakout from historical mindsets achieved to revitalise the future rather than simply replicate the past' (p. 196). Expanding this line of argument, some academics have argued that hospitality education should not wholly be defined by or reduced to serving the industry (Airey \& Tribe, 2000; Lashley, 2013; Lugosi et al., 2009). These perspectives echoed previous recommendations to expand the scope of hospitality management education by integrating wider disciplinary knowledge, for example from food sciences and performing arts (HEFCE, 1998). Arguably, these can be seen as attempts to challenge perceptions that it is a vocational subject and to legitimatise its place in higher education by intellectualising the field. These views contrast with that put forward by Wang, Ayres and Huyton who state that: 'Education in current political thinking, particularly since the 1990 s, is about equipping people for work. If education cannot supply job-ready people, then why would governments fund it and why would students choose it? Knowledge for knowledge's sake is an idealistic unaffordable luxury, and higher education must be relevant to the needs of employers' (2009:69).

Whilst employability remains a core driving principle in hospitality courses (cf. Jennings, Cater, Hales, Kensbock, \& Hornby, 2015; Stierand \& Zizka, 2015; Whitelaw \& Wrathall, 2015), academics also recognise that higher education should help develop rounded reflective practitioners who can contribute to a range of societal and professional spheres (Dredge et al., 2012; Morgan, 2004; Morrison \& O'Mahony, 2003). As Robinson, Kralj, Brenner and Lee's (2014) work suggests, this has driven the development of hospitality management teaching that seeks to create critical, reflective practitioners. This body of literature highlights that the challenge is to maintain credibility with different stakeholders who have potentially contrasting expectations of how hospitality education and research advances thinking and practice.

Other commentators have been more pessimistic, for example, pointing to the decline of funding for hospitality management in the UK higher education sector, 
especially in the delivery of practical training (Alexander, 2007; Alexander et al., 2009). The growing cost of providing the practical aspects of education has led to a withdrawal of investment. It could also be argued that the vocational focus of hospitality education has caused further frictions as universities seek to concentrate on higher-prestige, mainstream academic fields in positioning themselves in the global higher education market.

Much of the debate concerning the current state of hospitality education and the challenges regarding teaching and learning in the hospitality field has been based on literature and informed theoretical critique (cf. Lashley, 2013; 2015; Lugosi, Lynch, \& Morrison, 2009; Wood, 2015). As noted at the outset, empirical work on the current state of hospitality management education has concentrated on providing a descriptive overview of the landscape of provision rather than the specific challenges faced by academics and institutions in the field (cf. Breakey \& Craig-Smith, 2007; Jameson et al., 2006; Robinson et al., 2010). There is consequently a gap in knowledge regarding practitioners' viewpoints on some of the key challenges in the provision of hospitality management education. This paper thus attempts to address this gap by examining the experiences and perspectives of frontline academics involved in the management and delivery of hospitality in the UK higher education sector. This is significant for hospitality academics within and beyond the UK because it helps them to understand sectoral and institutional dimensions of constraints being encountered, how those are perceived and how individuals and organisations are responding to them. This in turn can help frontline practitioners and institutional managers re-evaluate their own strategic and tactical decisions regarding hospitality management education provision, which may involve divestment, investment, or the transformation of course content, focus and delivery. Examining disciplinary and institutional challenges in hospitality can also be instructive for tourism and events colleagues, supporting their desires to maintain their position in the (increasingly corporatized) international academic landscape.

\section{Study methods}

\subsection{Scope and focus}

The HEA were explicit in defining the overall scope and focus of the study. The research was conducted in the constructivist tradition (Lincoln \& Guba, 2013) seeking to co-create knowledge between researchers and participants regarding their perceptions of and feelings towards their professional experiences. The study considered six thematic areas: 1 . current key resources used in teaching in our subject area; 2 . learning and teaching challenges; 3 . the future evolution of teaching in the subject area; 4. gaps in current teaching and learning resources; 5. gaps emerging as a result of changes in our sector; and 6. ways in which Professional Associations, Learned Societies and the HEA can support learning and teaching in our field. However, as with all inductive research, within these broad headings, the discussions explored emerging themes that were raised by participants. Moreover, due to word limitations, this paper does not discuss the findings concerning learning 
and teaching resources that were addressed under the HEA's thematic areas 1, 4, 5 or 6.

\subsection{Sampling and data collection}

Participants for the study were recruited via email through the UK's Council for Hospitality Management Education's (CHME) database. Colleagues were sent an open invitation and 22 volunteered to participate (10 male; 12 female). The sample is made up of colleagues from 12 institutions in Scotland, Wales, England and Northern Ireland involved in hospitality education. Participants had taught a wide range of subject areas within hospitality degrees including food and beverage management, operations management, finance, economics, strategy, consumer behaviour, research methods, marketing, organisational behaviour and human resource management, food and drinks studies and events at undergraduate and postgraduate levels. The majority had course management responsibilities; and, apart from 2 participants, all were Senior Lecturers and above.

The recruitment method and sampling represented a series of risks and opportunities for the project. It could be argued that the opportunity to discuss the 'state' of hospitality appealed to colleagues who took a particular view of its past, present and its future, which has the potential to introduce bias into the general perspective being expressed. This, arguably, is a risk in all research that does not use a large-scale, probability sampling approach. However, it is important not to delegitimise any individual perspective or to privilege some as being more 'real' or valuable than any other. Each participant's experiences, interpretations and opinions should be seen as important but treated equally critically in the analysis process to avoid making unreasonable claims regarding a singular, definitive or reductive representation of reality.

Moreover, within the data generation, participants were actively encouraged to express contrasting opinions. There were numerous instances where participants presented contrasting views, and the data generation articulated multiple different perspectives on the hospitality sector. Furthermore, the self-selection aspect of the sampling and recruitment helped to identify colleagues from a range of institutions, geographical locations and subject expertise, thus providing a richness and diversity of experiences.

The data were generated through four group interviews. Two were conducted physically: one during CHME's 2015 annual conference and the other at one of the participant's institution. In addition to this, two virtual group interviews were held using internet-based meeting software. All the interviews were recorded and additional notes were made by the lead interviewer.

\subsection{Data processing and analysis}

The interviews were transcribed by a third party, and subsequently analysed thematically by the authors (Braun \& Clarke, 2006). Two researchers coded the data in parallel to reduce the potential bias of single person coding (cf. Thomas, 2006). The analyses were subsequently brought together under one unified reduced data set; and, as MacQueen, McLellan-Lemal, Bartholow and Milstein (2008) suggested, one 
researcher collated and organised the final coding scheme. Through this process the original 53,247 words of raw transcribed data were reduced to 25,718 words and ordered into 40 thematic groups, under the six broad areas identified by the HEA.

\section{Findings and discussion}

\subsection{Engaging the contemporary student}

A strong theme to emerge from all the interviews was the increasing challenges associated with weakening student engagement. Specifically, attendance was often linked to the perceived value of the particular session i.e. whether it was assessed or had direct links to assessment. One participant said:

If the lesson is related to how they're going to be assessed, I'll get $100 \%$ attendance, so I generally tell them it's related to the assessment every week and then I get great attendance! But they are very much assessment-driven. It's quite scary how if they don't think it's related to the assessment they just don't think they need to come!

Moreover, the instrumental and fragmented nature of student engagement was linked more widely to the changing characteristics of students and their approach to learning. In part, these were seen as generational problems. Educational researchers, including in hospitality, have considered the differences in the learning styles of 'Generation $Y$ ' students (Barron, 2008; Lashley \& Barron, 2006; Shaw \& Fairhurst, 2008; Weiler, 2005). These works highlight the importance for contemporary students of stimulation and creative content, the adoption of a more fragmented approach to learning, and a desire to access information in non-traditional (printed) formats, often using technology. Among our participants, students were perceived to want information in smaller, more easily consumable packages. They were seen to have short attention spans and there was increasing pressure on lecturers to entertain students to keep them engaged. One participant said:

I think the student profile has changed quite a lot and I think that asking students to read chapter after chapter is not necessarily the way that they choose to access information these days, but if you give them a series of web links to different things and they can look into our virtual learning here at the university, that's perhaps the more acceptable way for our student base to be looking at things. They like the bite-size chunk stuff and they like to have that mixed in. I don't think they do well being asked to stick with textbooks these days.

Colleagues also felt they needed to provide increasing support on how to obtain and interpret information. There was less evidence of independent learning and students were asking for greater levels of guidance on how to solve basic problems and approach assessments. One participant said: 
The more we give them, the more they ask for. And they're literally saying in the classroom, 'Which chapter do I need to read?' So you might call it strategic learning, you might call it surface learning, but it's certainly not deep learning.

Importantly, the perceived decline in meaningful engagement with academic content and 'deep-learning' was linked to technology. As a colleague noted:

I think there's something else as well, which I call 'the Google generation', which is about reading represents knowing, which isn't the case. You can look up something on Google and register what it says without really knowing about the subject. I think we face students, many of whom have that sort of view of knowledge, that it's available, it's accessible, it just needs something to be typed into Google and then that's the answer. And I think that's not knowledge, that's information.

Technology was seen to exacerbate the intellectual deskilling and fracturing of engagement of students. There was general agreement that students were increasingly relying on search engines and were uncritical consumers of knowledge.

Extending the technology-engagement debate, when another participant questioned 'how much time ... students actually [spent] reading all of this [academic] material that's available', another colleague observed: 'I watch them in the library, they're on Facebook, on their phones, they're on the screen for a second.....honestly, it's amazing to watch them.' Such multitasking behaviour and its negative impact on attention, learning and the effectiveness of teaching is a growing topic of concern for academics and teachers beyond hospitality (see e.g. Bellur, Nowak, \& Hull, 2015; Sana, Weston, \& Cepeda, 2013; Terry, Mishra, \& Roseth, 2016). Echoing this sentiment, the greater presence of tablets, mobile devices and notebooks in class was perceived by some lecturers to be a distraction and they felt less confident that students were paying attention to the teaching.

It is important to stress, however, that students' use of technology for learning more generally was seen in contrasting ways by colleagues. There was general agreement that students were more technology dependent and wanted more content available online, which they could access in times and places convenient to them. Some colleagues felt that making teaching material available online could also discourage attendance; although research on this found that podcasts did not necessarily result in declining class attendance (e.g. Bryans-Bongey, Cizadlo, \& Kalnbach, 2006). Copley's (2007) research suggested that students mostly accessed podcasts for revision and assignment preparation rather than as a substitute for lecture attendance. Echoing previous empirical research, there was evidence in our participants' experience that many students used technology constructively, for example using recorded lecture content to go over class material, and that it did not always impact negatively on attendance. One participant was very enthusiastic about the positive impact of recording lectures: 
I've been using lecture capture for three years so all of my lectures and my modules have been recorded and I do them myself, I've got my own equipment and I do it through Adobe Connect. Students love it, and you know what? Apart from that last couple of weeks when there's deadlines, the attendance is fantastic, no different to how it was before I did it and those that can't make it, some of them are online. They're all recorded so they can download them and play them on their iPads later, and the feedback is amazing.

As noted above, the challenges associated with student engagement and the rise of technology are not limited to hospitality (Bellur et al., 2015; Sana et al., 2013; Terry et al., 2016). Colleagues are also acutely aware of the need to develop new technologies alongside innovative teaching techniques to engage students, and to understand how they learn through technology (cf. Green, Chang, Tanford, \& Moll, 2015; Hsu, 2012; Lugosi, 2010; Ma \& Au, 2014). There was general consensus among the participants that technology will be central to the future of higher education. This is likely to involve ongoing development of online content and supporting services, including increased use of lecture capture, and the use of blended delivery. Sanders and LeClus (2009) in discussing the changing nature of the learning experience similarly acknowledged that emerging technologies add new dimensions of richness and complexity to the 'traditional' learning experience. However, they recognised that: 'it would be unfair to assume that all university students have enhanced information literacy' (2009:94), which stresses the need to avoid overgeneralising or taking a reductive view of students and their use of technology. Sanders and LeClus (2009) also recognised that 'teaching staff may not be as technologically adept or enthusiastic at incorporating learning technologies into their existing pedagogy' (2009:94), which they argued was one component of the 'digital divide' between educators and learners.

Some of our respondents saw the growing role of IT and online delivery more generally as threats to the fundamental craft of hospitality management. It was argued that because hospitality was so people-centric, reliance on online delivery meant that key interpersonal and communication skills and technical competencies could not be developed effectively and would reduce students' employability. However, others disagreed that online delivery would replace on-campus delivery completely for several reasons. Firstly, online delivery was less effective for developing hospitality graduates; secondly, many students still desired personal contact; and thirdly, the delivery of effective online courses was labour-intensive and therefore it did not represent a clear cost saving for institutions.

\subsection{International students}

A significant theme across the interviews concerned the challenges associated with international students. As one participant observed:

I think there's too much assumption about learning and not enough emphasis on the role of culture, because education is cultural, so if 
somebody comes to us from Asia, South America, Africa, they'll have been through a different educational system and we assume that they know certain things or know how to do certain things.

The growing number of international students had led to the development of new sensitivities and imperatives. In some courses the dominant numerical presence of students from one or two nationalities influenced the dynamics of learning and teaching, and the student experience more widely. Language proficiency was perceived as a significant challenge, with students not being able to engage with the subject because of their limited grasp of English. However, several colleagues noted that there were broader cultural issues with international students. Firstly, integration between national groups was a problem for lecturers and students. International students entering short, intensive master's courses in particular struggled to adjust to the UK educational environment. These problems were amplified by poor language skills and by joining the course in January rather than September, an entry option available at several of our participants' institutions. Secondly, it was noted that some students from Asian backgrounds were still uncomfortable with speaking out in class or questioning issues, although others acknowledged that it was important to avoid generalising and there was significant difference in students, even those from the same nation.

In response to some of these challenges, colleagues were investing more in preentry screening to identify learning needs, in preparatory courses to develop key competencies, as well as in induction and specialist training activities to support students' understanding of UK educational practices. Many colleagues also said they had adjusted their learning and assessment strategies. For example, as one participant observed:

We're trying to come up with assessments which will be suitable for testing learning outcomes in the cohorts which we've got, and we tend to include more technology and so they are involved either on their mobile phones or their iPads or tablets, and we're introducing more of that, like online discussion boards or discussions in class rather than in the past we used to have more of the written pieces, reports or essays, so we're trying to diversify and include a variety of different types of assessment to provide students with opportunities to communicate on various levels, and probably to help them to overcome problems with English in some cases.

Importantly, colleagues also saw it as important to develop (inter-)cultural sensitivities amongst international and domestic students studying on the same courses. Building resilience in students alongside understanding towards others was viewed by several participants as part of a broader 'duty of care'.

Similarly to the themes regarding technology, the challenges of multicultural learning environments, particularly for members of different national and ethnic groups are certainly not unique to hospitality, and hospitality education researchers 
have grappled with the challenges they present (Barron \& Arcodia, 2002; Lashley \& Barron, 2006; Robinson et al., 2014). Importantly, internationalisation is arguably inevitable for much of the higher education sector. The globalised and highly competitive nature of higher education has led to greater effort being put into targeting international students. A critical reading of these strategic decisions is that they represent a lucrative consumer segment and help to ensure the financial sustainability of courses and institutions. A broader reading is that widening economic prosperity, and social mobility, driven by social factors (e.g. peer influence, social media and chain migration), political facilitators (e.g. relaxed visa policies) and technological innovations (e.g. the lowering costs of travel and communication technologies) has led to a growing number of nationalities studying abroad. In short, a more diverse student body is an inevitable outcome of globalisation and societies characterised by mobility (Urry, 2007). Finally, a more positive reading of the growing internationalisation of higher education is that it has the capacity to increase intercultural knowledge and cultural sensitivity. However, it is clear that managing an increasingly diverse set of students places strains on the student experience and the institutions trying to accommodate multiple demands, from domestic and international students.

\section{3 'Innovative' and 'efficient' course designs}

A strong emerging theme concerned the challenges to learning, teaching and assessment caused by new programme designs. Universities were perceived to be seeking to deliver courses in more efficient ways. This included developing larger modules or units that could be delivered across multiple subject groups, particularly in generic areas such as research methods, organisational behaviour and marketing. In the institutions where this was utilised, this had led to larger lectures and to a lack of contextualisation to the hospitality area. Both of these were perceived as weaknesses in current course design, and also as loss of control by hospitality colleagues.

Linked to the previous points, the use of modular programmes was also perceived to be a challenge. In part this has led to a loss of cohort identity and staff did not know each student personally. Modular programmes and the resulting mixed cohorts were also seen to disrupt the linearity of learning. Lecturers could no longer take for granted that students had covered concepts in previous classes and so they could not build on a shared knowledge base. This frequently required staff to teach subjects at a more basic level to accommodate students who did not have sufficient grounding, which was felt to be unfair to others who had a stronger underpinning. Several colleagues noted that similar experiences in their institutions had led them to revise their course structure and (re)adopt a linear approach.

Finally, colleagues from some institutions said that they were required to construct new programmes involving fewer modules with larger individual credit values, and to reduce the number of module or unit options available to students. Colleagues saw this as being driven by a desire for economic efficiency rather than pedagogic excellence. This has led to a decrease in subject specialism, which was also 
seen to make the course less attractive to students, including to international students on exchange programmes, who wanted greater choice.

\subsection{Institutional constraints and the intensification of work}

Following on from the previous theme of new course designs, institutional and occupational tensions emerged across the interviews. Some of these challenges were specific to individual organisations, but others reflected general trends within the higher education sector and the teaching profession. Growing managerialism and bureaucratisation within the sector were seen to inhibit innovation in teaching. For example, class times and delivery patterns were heavily prescribed. There were also increasingly constraints on the availability of space, and the layout of teaching spaces could not be reorganised to facilitate alternative, interactive lesson formats.

The majority of participants identified ways in which a variety of new technologies were increasingly being embedded into their learning and teaching. A small number of people felt this to be a challenge as it required investment in the development of new IT competencies. However, most were keen to embrace new technologies, despite the fact that their potential could not always be realised because of other pressures. As one participant commented:

We've got technology, but intensification of our workloads means that we don't have time to do what the technology could do for us, because we can't step back. In the 14 years I've been teaching in higher education I've seen the space I used to have to innovate and be creative and spend time thinking about my job has disappeared. Gradually, year after year after year it's shrunk, and now I'm in a position where I can just keep going and I can do little bits, I can tinker at the edges, but I can't sit down and rewrite and do a module in a totally different way that I could have done ten years ago.

In discussing institutional constraints, participants identified a number of issues that were specific to hospitality management education. A dominant and recurring set of themes were the availability and use of practical facilities that support experiential learning. Wood (2007:6) has argued that: 'food and beverage management features as a significant part of the curriculum in most hospitality management courses'. Wood continued, claiming that: 'nearly all modern courses in hospitality management include, and cling to, a model of food and beverage management education that is training and operations oriented as reflected in core courses that require students to spend some of their time in kitchens learning how to prepare food for service in restaurants, and some of their time in hotel school training restaurants serving the food that has been thus prepared. The model is a globally familiar one, even allowing for variants'.

Participants from across the different institutions agreed that practical training was a central element of hospitality management education. One participant said: 
If we were to lose our practical facilities we would lose all the skill base from that vocational degree, we would lose our ability for them to develop menu stuff later on, we would lose the ability to then go down and simulate some other situations, and that would be dreadful, but I think there was a huge economic pressure on having practical facilities, and that I think is a big one, a big challenge to maintain that.

Some of the participants were more sceptical about how much students actually learned by using the practical facilities. As one said: 'So by the time they go on placement in their second year they know the difference between a knife and fork and they know that an oven is hot but not much more.' Nevertheless, the majority of participants felt that practical facilities elements were important to their provision.

However, irrespective of colleagues' views of practical facilities, these are expensive and many institutions had eliminated them to reduce costs, which added further complexities to the delivery of hospitality management courses. Colleagues from these institutions had to deal with the additional challenge of providing practical training by outsourcing these parts of the courses to specialist operators including cooking schools, further education establishments or industry partners. One participant said:

We have a partnership with a cookery school in [this city] ... and we also have a partnership with [a hotel] where our students go and work in the different departments within the hotel and get their practical experience from those two places, but that's not on campus. I can see a situation whereby more partnerships like the one we have here ... are going to be used, where elements of catering and hospitality education are going to be outsourced because it's expensive to do, equipment's expensive and it's expensive to staff, so I think it's cheaper to use outside bodies. And I can also see more partnerships like the one we have with the [hotel] may become obvious paths in education in terms of how we deliver the practical performance of food service and accommodation... which is different from having a realistic working environment or an in-house restaurant, a slightly different way of doing it, and again, given that finances are ... increasingly tight, it's also cheaper for us to do it that way. [The hotel] is free, we don't pay for that, so from a very practical perspective that helps the finance of our course.

Wood (2007) discussed the trend of outsourcing food and beverage training to local technical colleges with pre-existing kitchen and training restaurant facilities. He observed that numerous institutions with their own facilities had already begun to dispense with them and followed a similar path to that described by our respondent above. Wood (2007: 7) argued that Universities 'rarely see investment in training kitchens and restaurants as equivalent to investment in the laboratories demanded by natural scientists!' Similarly, Breakey and Craig-Smith conducted research on hospitality degree programmes in Australia and concluded that: 'there has been a 
progressive move away from a strongly focused practical hands-on emphasis in cooking, food service and hotel operation to a greater emphasis on service quality, total quality management, technological applications in the industry and globalisation. Students are encouraged to obtain the more practical training through on-going employment' (2007:114).

In our research, the institutions that retained practical facilities were seen to be in a stronger market position and participants from institutions that still had them all claimed that these were significant assets, although they also recognised that the cost made courses and facilities vulnerable. This echoed Wood's earlier observation (2007:7): 'The sheer costs of investing in (and maintaining) the facilities required for this educational model are not always palatable to the higher education institutions that host hotel schools'.

\subsection{Business schools and the position of hospitality management}

Roberts (2009) suggested that the (re)location of degree-level tourism and hospitality management programs in faculties and schools of business and law, was driven by a desire to enhance the status (and thus legitimacy) of the qualification through a management focus. Importantly, according to Bird, van de Mortel, Holt and Walo, (2015:20), 'many undergraduate programs were taught as combined degrees with arts, social science and business schools where the curriculum is taught by a multidisciplinary team of lecturers, only some of whom are [subject] experts'. As noted above, our respondents stressed that similar 'shifts' in the UK hospitality higher education sector had led to a number of generic subjects such as marketing and human resource management being taught by non-hospitality academics, which was seen to create several challenges. Firstly, the lack of specialisation limited students' development of necessary applied knowledge and understanding. Secondly, some colleagues in our sample felt this 'dilution' of their subject specialism posed risks to a sense of identity among hospitality academics, further undermining the visibility and status of hospitality management in some institutions. As one participant surmised:

I think a challenge is, when you're moving into a business school, you can lose your identity because you become part of this big powerful business school and you're a small cog in this big system. Most of us will be in business schools and therefore how do we survive, how do we prosper within a business school? I think that's an issue.

Other colleagues, however, seemed to see this as an inevitable development trajectory for hospitality management provision and saw the teaching of hospitality within generic business-focused courses as a legitimate survival strategy.

The tensions between hospitality's intellectual development and the constraints in its provision also need to be seen in the broader context of higher education and research. The UK Research Assessment Exercise (RAE), now the Research Excellence Framework (REF), and the growing influence of ranking exercises and journal quality guides have presented a number of challenges for the field. Hospitality has often 
been included in Business and Management submissions in the RAE and REF, which has not always served it well (Litteljohn, 2004). Furthermore, prior to 2015, hospitality journals were ranked less highly in the Association of Business Schools' Academic Journal Guide. The position of hospitality journals improved in the revised 2015 edition of the Guide. It is also useful to highlight that hospitality journals performed much better in other international ranking exercises, for example in the 2013 Australian Business Deans Council's Journal Quality List. Nevertheless, research assessment exercises and associated metrification practices have not helped hospitality; and, coupled with the rising cost of its provision, these pressures undoubtedly discouraged institutional investment in learning and teaching in this area.

The problems raised by the growth of research metrics and audit cultures are not unique to hospitality (Ayikoru et al., 2009; Butler \& Spoelstra, 2014; Mingers \& Willmott, 2013). However, the historical development and vocational focus of hospitality education means that their impacts may affect learning and teaching in this area more acutely than other branches of management education. It is also important to stress that this situation has changed somewhat, with recent analyses suggesting that there has been significant growth and maturing of hospitality research overall (Lynch et al., 2011; Rivera \& Upchurch, 2008; Rivera \& Pizam, 2015; Ryan, 2015). Nevertheless, the pressure to strive for 'research excellence', however this is defined, will continue to be another driver shaping learning and teaching in hospitality. Research productivity will have to co-exist with the desire to maintain strong links with industry and to provide excellent 'employability-focused' student experiences, with fewer resources. Emerging evaluation initiatives such as the Teaching Excellence Framework (TEF) in the UK are likely to increase pressures on colleagues and institutions by expanding cultures of surveillance, auditing and bureaucracy.

\subsection{Tensions between academia and practice}

A further challenge for hospitality colleagues was the perceived tension between academia and the academic teaching of hospitality and the practical nature of hospitality management, which has been acknowledged previously by commentators (see e.g. Raybould \& Wilkins, 2006). Colleagues in our study felt they had to justify their learning and teaching approaches to multiple stakeholders with different priorities and values. Some of our respondents suggested that the quest for legitimacy was operating on a more fundamental level - centred on practitioner recognition of the value of higher education. For example:

I think another big challenge for us, to me, is industry engagement and making the hospitality industry realise they need graduates. I think they've struggled with that concept of the need for graduates, because they weren't graduates themselves. I actually think that there is a glimmer of light at the end of the tunnel there, but there's a long way to go, so this engagement with industry I think is critical. 
Beyond the need to demonstrate relevance in general, our respondents felt that practitioners wanted graduates who could step into intensive management roles straight after leaving university. This view was highlighted in previous discussions of 'job-ready graduates', for example by Wang et al. (2009:62) who posited that: 'tourism higher education, as a major platform for human capital development for the tourism industry has a mission to assure the quality of graduates and equip them with the particular skills and attributes to enable them to function as sophisticated professionals'. The unease associated with such discourses of 'job-ready' graduates was reflected in our respondents' narratives, for example:

....there's increasing expectation from employers that we are going to produce more oven-ready graduates who are able to hop into any particular establishment that the employer demands and basically be up and running, and I think that has implications for us in terms of how we teach. There's a balance there between educating and training people for the workforce, which is not what we're about necessarily, and I do think that employers do demand quite a lot and I think that demand will increase perhaps as well.

Many of our respondents questioned the extent to which such discourses do and should wholly define the scope, content and raison d'être of hospitality management education. Colleagues argued that higher education should not simply serve the industry and thus teaching should not be limited to training for operational or management skills. As one contributor noted:

I'm not sure we always help ourselves sometimes by being seen as a sort of conveyor belt for managers for industry... we'll always be vocationally oriented to provide people with the skills, hard and soft skills that the industry needs, but I think it's a mistake to let industry think that that's all we're for, and I think it's a mistake for us to think that's what we're for.

This view is supported in the literature, for example by Airey and Tribe (2000) who argued that tourism education must do much more than reflect the immediate needs of the workplace or the immediate demands of entry-level employment positions. Nevertheless, participants acknowledged that they wanted to develop highly employable graduates who were prepared to take on hospitality management positions, which drove them to defend hospitality-specific teaching, including the maintenance of practical and experiential elements of hospitality courses, which was not always easy in a business school.

\subsection{The future of hospitality educational provision}

Colleagues generally agreed that the challenges identified above are going to intensify in the future, driving innovation in higher education in general and hospitality management education specifically, and placing additional burdens on academic staff. However, there was disagreement about the form and scope of the 
changes. Two emerging themes were the creation of new partnerships and new modes of delivery.

Colleagues from several institutions said that the need to reduce costs and the desire to maintain close links with management practice will drive the development of new partnerships. More of the practical training and experiential learning will take place outside of traditional university spaces and models. University staff will continue to provide academic input but practical learning will be led by hospitality professionals, and increasingly done in workplaces. It was acknowledged that this has associated challenges particularly in assuring consistency in learning and teaching experiences. Student and practitioner expectations and inputs will have to be managed carefully to maintain these learning and teaching models.

It was felt that the future of hospitality management education will involve new models of delivery and programme designs. The well-recognised changes in the higher education environment and the current profile of hospitality students are likely to lead to new forms of educational provision and partnership models (cf. Feng, Chiang, Su, \& Yang, 2015; Pang, Wong, \& Wong, 2013; Pizam, Okumus, \& Hutchinson, 2013; Zwaal \& Otting, 2015). It may also be the case that future provision may involve new, privately-financed educational providers.

Participants in one interview raised the prospect of two-year undergraduate degrees, a strategy adopted in some private educational institutions, which would require intensive, three-term teaching. Colleagues considered the impacts of this approach on learning and the student experience. It was felt that the reduction in fees and living costs could make this attractive, although there were concerns around the impacts on engagement and the overall student experience. The development of two-year master's programmes was also suggested to help students, especially international ones, to settle and develop at a more suitable pace.

It was also felt that institutions seeking to keep their practical provision will also have to continue to develop financial and management models that ensure facilities can generate income and be utilised by other courses or institutional stakeholders. This is likely to require practical facilities to be much more externally facing, creating multiple income streams, opening for longer periods and adopting flexible approaches to staffing. Again, managing the different expectations of students, customers, staff and university administrators is going to be a challenge as learning and teaching will only be one of its functions.

Finally, numerous participants also highlighted how the growing popularity of events management was changing learning and teaching in hospitality. The demand for events-related teaching was perceived to drive greater integration of events elements into hospitality courses and the development of event-hospitality hybrid courses to sustain hospitality management provision in institutions. It was felt that failure to do this could undermine hospitality provision as students opted for events modules, units or courses instead of hospitality ones. In some institutions, colleagues noted a sense of tribalism: events staff sought to create an academic identity that was distinct from hospitality and tourism, which constrained joint teaching provision.

The rise in popularity of events management can thus be seen as a threat and an opportunity for hospitality. It is a threat insofar as it attracts some students away 
from studying hospitality. However, incorporating elements of events management into hospitality courses, which is already evident, offers opportunities to enhance the content and appeal of hospitality. Furthermore, event management often involves hospitality management principles and practices, so event management courses may benefit from integrating hospitality elements into their courses. For example, this may involve using practical kitchen and restaurant facilities previously used exclusively for hospitality operations training. The ability to create and capitalise on such synergies may depend on the strategic cooperation of hospitality and event colleagues. However, events, like hospitality has attempted to create a distinct identity in the academic marketplace as it has evolved (cf. Getz, 2002; Kashef, 2015; Silvers, Bowdin, O'Toole, \& Nelson, 2005). The desire to maintain distinctiveness may result in further academic tribalism, which undermines cooperation in the long term.

\section{Conclusion}

There is no doubt that the higher education sector in general and hospitality education in particular is facing significant challenges. We provide a summary of key challenges identified in our study in Table 1. As our data and reading of the literature have shown, the marketization of higher education, the globalised nature of competition for educational provision, and changes in the funding of higher education has required institutions to scrutinise the scope and form of hospitality management education. Our data reflect the challenges caused by the constriction of hospitality management education and its integration into business and management schools and faculties. Moreover, we have examined how these processes, interacting with more general practices of management surveillance, measurement and valuation, and initiatives to drive efficiency, have radically reshaped hospitality management education. Its provision has thus moved away from traditional, sectorspecialised craft-centric models of delivery towards ones that are more closely aligned with general management and business fields. At the same time, hospitality academia has sought to develop its unique intellectual identity and directions whilst attempting to maintain its relevance to commercial practice and its practitioners. These challenges have emerged at the same time that pedagogic practices and the nature of student engagement across multiple domains of higher education are transforming - adopting new values and technologies that are themselves disruptive.

It is possible to argue that the majority of challenges and debates highlighted in this study reflect ones that have been (re)emerging throughout the history of hospitality management education. However, this should not be seen as a failure of the subject to evolve. Practitioners in other fields also continue to engage in debates concerning the fundamental purpose of their endeavours and the tensions between theorising, academic credibility, practitioner focus and 'real-world' impact (see e.g. Biggart, 2016). The continuing practice of critical reflection should therefore be seen as the ongoing maturation of the subject area: questioning its practices and stakeholders, and the challenges involved, is key to its future survival.

As previously suggested, hospitality management provision in the future could indeed be enhanced by incorporating other disciplinary influences, ranging from arts, humanities as well as the social and 'harder' sciences (cf. HEFCE, 1998; Lashley, 2008; 
Lugosi et al., 2009). These may help to give the subject further legitimacy in the wider higher educational landscape. However, any such disruptive innovation will have to operate in an environment with growing managerialism, globalised market competition and increasingly complex socio-cultural, technological and political forces.

Moves by individuals and institutions to integrate hospitality into more general management degrees may be seen as a dilution of its provision but it can be seen by colleagues within and beyond Anglospheric parts of the world as opportunities to maintain their distinctiveness by continuing to provide tailored hospitality management education that develops sector-specific competencies through experiential learning. The threats of provisional constriction should also be seen alongside the flourishing of hospitality (management) scholarship that has helped to develop the intellectual credibility of the field. The combination of scholarly selfreflection, institutional constriction and the pressure to achieve 'higher levels' of pedagogic outcomes and research outputs may therefore result in hospitality management education surviving as a smaller but intellectually stronger area of higher education in the UK and other parts of the world such as Australia. Such decreasing competition and greater academic credibility may also help educational providers in the Middle East, Asia and South America to thrive.

The study is limited to UK academics and we do not claim to have assembled a representative sample. Therefore we encourage future research that explores further, through larger and more representative samples, how the challenges identified here emerge elsewhere, in UK and international contexts. The themes highlighted through this study could also inform further quantitative studies that link these challenges with issues such as staff satisfaction, turnover and productivity. Importantly, future studies can and should also explore further how individual and collaborative solutions are enacted within organisational settings, including the factors that facilitate or inhibit positive change.

\section{Table 1. Summary of key challenges identified}

- There is a perceived increase in the fragmentation of student engagement and growing instrumentality in their learning.

- Evidence of independent thinking and learning is decreasing and students are requesting information to be provided in smaller, accessible units, and with greater curation by teaching staff.

- Technology and internet access to information is shaping how students engage with learning and teaching, leading to a perceived decline in the critical consumption of information.

- Students' multitasking with technology is often seen to exasperate fragmented engagement and disrupt 'deep learning', particularly during classes.

- Technology can also be used to enhance delivery and support flexible engagement for students, for example in the use of lecture capture and podcasting. However, it requires the development of new competencies and processes; its development and utilisation is dependent on staff and the 
institutions' willingness and ability to invest in resources, which may not always be viable as competition for resources and pressures for outputs increase.

- The growing presence of (and institutional marketing focus on) international students will continue to present challenges for the student and staff experience.

- Institutional strategies looking to make efficiency gains through course designs with generic content and mixed cohorts will undermine specialised hospitality management education.

- The intensification of work, with growing managerialism, is likely to place increasing pressure on staff who have to meet widening sets of performance indicators.

- There will be growing pressure on institutions with practical facilities to justify their maintenance, create new uses and/or revenue streams for facilities, or to find alternative models to provide practical experience.

- The location of hospitality management programmes in business schools and faculties is likely to continue to threaten the distinctiveness of hospitality management programmes.

- The addition of research performance evaluation exercises such as the UK's REF will continue to place additional pressures on staff to produce 'excellent' research in an increasingly competitive environment.

- The debate concerning the tensions between theory and practice, and the need to drive intellectual credibility whilst maintaining relevance to practitioners will continue.

- The future of hospitality will most likely require the establishment of new partnerships and new models of delivery to a) underpin employability, b) help maintain the relevance of education to practice and $c$ ) ensure the financial viability of courses. New models may require greater use of work-based learning, the outsourcing of practical teaching and may involve further partnerships with commercial organisations. The involvement of further stakeholders will create new challenges around the management of (potentially incompatible) values, expectations and resources.

- The rise of events management may undermine the viability of hospitality management education and scholarship, particularly if it leads to greater academic tribalism and events courses attract students away from hospitality.

\section{References}

Airey, D., \& Tribe, J. (2000). Education for hospitality. In C. Lashley, \& A. Morrison (Eds.), In search of hospitality: Theoretical perspectives and debates (pp. 27692). Oxford: Butterworth-Heinemann.

Alexander, M. (2007). Reflecting on changes in operational training in UK hospitality management degree programmes. International Journal of Contemporary Hospitality Management, 19(3), 211-220.

Alexander, M., Lynch, P., \& Murray, R. (2009). Reassessing the core of hospitality management education: The continuing importance of training restaurants. Journal of Hospitality, Leisure, Sport \& Tourism Education, 8(1), 55-69. 
Ayikoru, M., Tribe, J., \& Airey, D. (2009). Reading tourism education: Neoliberalism unveiled. Annals of Tourism Research, 36(2), 191-221.

Ball, S. J. (2012). Performativity, commodification and commitment: An I-spy guide to the neoliberal university. British Journal of Educational Studies, 60(1), 17-28.

Barron, P. (2008). Education and talent management: Implications for the hospitality industry. International Journal of Contemporary Hospitality Management, 20(7), 730-742.

Barron, P. \& Arcodia, C. (2002). Linking learning style preferences and ethnicity: International students studying hospitality and tourism management in Australia. Journal of Hospitality, Leisure, Sport \& Tourism Education, 1(2), 1527.

Bellur, S., Nowak, K. L., \& Hull, K. S. (2015). Make it our time: In class multitaskers have lower academic performance. Computers in Human Behavior, 53, 63-70.

Biggart, N.W. (2016). Biggart's lament, or getting out of the theory cave. Journal of Management Studies, 53(8), 1381-1387.

Bird, J., van de Mortel, T., Holt, J., \& Walo, M. (2015). Academics' perceptions of continuous and collaborative curriculum review: An Australian case study. Journal of Hospitality \& Tourism Management, 24, 18-24.

Braun, V., \& Clarke, V. (2006). Using thematic analysis in psychology. Qualitative Research in Psychology, 3(2), 77-101.

Breakey, N. M., \& Craig-Smith, S. J. (2007). Hospitality degree programs in Australia: A continuing evolution. Journal of Hospitality \& Tourism Management, 14, 102118.

Bryans-Bongey, S., Cizadlo, G., \& Kalnbach, L. (2006). Explorations in course-casting: Podcasts in higher education. Campus-wide Information Systems, 23(5), 350367.

Bulman, S. (2015). Teaching and learning in the disciplines: An HEA-funded project. Summary Report. York: The Higher Education Academy.

Butler, N., \& Spoelstra, S. (2014). The regime of excellence and the erosion of ethos in critical management studies. British Journal of Management, 25(3), 538-550.

Cheng, Y. (2016). Learning in neoliberal times: Private degree students and the politics of value coding in Singapore. Environment \& Planning A, 48(2), 292308.

Copley, J. (2007). Audio and video podcasts of lectures for campus-based students: Production and evaluation of student use. Innovations in Education \& Teaching International, 44(4), 387-399.

Dredge, D., Benckendorff, P., Day, M., Gross, M. J., Walo, M., Weeks, P., \& Whitelaw, P. (2012). The philosophic practitioner and the curriculum space. Annals of Tourism Research, 39(4), 2154-2176.

Dredge, D., Benckendorff, P., Day, M., Gross, M. J., Walo, M., Weeks, P., \& Whitelaw, P. A. (2013). Drivers of change in tourism, hospitality, and event management education: An Australian perspective. Journal of Hospitality \& Tourism Education, 25(2), 89-102. 
Feng, L., Chiang, M. H., Su, Y., \& Yang, C. C. (2015). Making sense of academiaindustry cooperative teaching. Journal of Hospitality, Leisure, Sport \& Tourism Education, 16, 43-47.

Fullagar, S., \& Wilson, E. (2012). Critical pedagogies: A reflexive approach to knowledge creation in tourism and hospitality studies. Journal of Hospitality \& Tourism Management, 19, 1-6.

Getz, D. (2002). Event studies and event management: On becoming an academic discipline. Journal of Hospitality \& Tourism Management, 9, 12-23.

Green, A. J., Chang, W., Tanford, S., \& Moll, L. (2015). Student perceptions towards using clickers and lecture software applications in hospitality lecture courses. Journal of Teaching in Travel \& Tourism, 15(1), 29-47.

HEFCE (1998). Review of hospitality management. Bristol: HEFCE.

Hsu, L. (2012). Web 3D simulation-based application in tourism education: A case study with Second Life. Journal of Hospitality, Leisure, Sport \& Tourism Education, 11(2), 113-124.

Jameson, S., Walmsley, A., \& Ball, S. (2006). A review of hospitality management education in the UK. Leeds: Council for Hospitality Management Education.

Jennings, G., Cater, C. I., Hales, R., Kensbock, S., \& Hornby, G. (2015). Partnering for real world learning, sustainability, tourism education. Quality Assurance in Education, 23(4), 378-394.

Jones, P. (2004). Finding the hospitality industry? Or finding hospitality schools of thought. Journal of Hospitality, Leisure, Sport \& Tourism Education, 3(1), 3345.

Kashef, T. E. (2015). What is the value of event management education? The views of six industry practitioners. Event Management, 19(1), 1-13.

Lashley, C. (2008). Studying hospitality: Insights from social sciences. Scandinavian Journal of Hospitality \& Tourism, 8(1), 69-84.

Lashley, C. (2013). Managing the tyranny of relevance: Linking with industry-but not too much! Worldwide Hospitality \& Tourism Themes, 5(3), 283-295.

Lashley, C. (2015). Hospitality studies: Escaping the tyranny? Quality Assurance in Education, 23(4), 364-377.

Lashley, C., \& Barron, P. (2006). The learning style preferences of hospitality and tourism students: Observations from an international and cross-cultural study. International Journal of Hospitality Management, 25(4), 552-569.

Lincoln, Y. S., \& Guba, E. G. (2013). The Constructivist Credo. Walnut Creek, CA: Left Coast Press.

Litteljohn, D. (2004). The UK research assessment exercise 2001: An analysis for hospitality research. International Journal of Hospitality Management, 23(1), 25-38.

Lugosi, P. (2009). Ethnography, ethnographers and hospitality research: Communities, tensions and affiliations. Tourism \& Hospitality: Planning \& Development, 6(2), 95-107.

Lugosi, P. (2010). Computer assisted self and peer assessment: Applications, challenges and opportunities. Journal of Hospitality, Leisure, Sport \& Tourism Education, 9(1), 85-91. 
Lugosi, P., Lynch, P., \& Morrison, A. (2009). Critical hospitality management research. The Service Industries Journal, 29(10), 1465-1478.

Lynch, P., Germann Molz, J., McIntosh, A., Lugosi, P., \& Lashley, C. (2011). Theorizing hospitality. Hospitality \& Society, 1(1), 3-24.

Ma, C., \& Au, N. (2014). Social media and learning enhancement among Chinese hospitality and tourism students: A case study on the utilization of Tencent QQ. Journal of Teaching in Travel \& Tourism, 14(3), 217-239.

MacQueen, K.M., McLellan-Lemal, E., Bartholow, K., \& Milstein, B. (2008). Teambased codebook development: Structure, process, and agreement. In G. Guest \& K. M. MacQueen (Eds.), Handbook for team-based qualitative research (pp. 119-35). Lanham, MD: AltaMira Press.

Mingers, J., \& Willmott, H. (2013). Taylorizing business school research: On the 'one best way' performative effects of journal ranking lists. Human Relations, 66(8), 1051-1073.

Morgan, M. (2004). From production line to drama school: Higher education for the future of tourism. International Journal of Contemporary Hospitality Management, 16(2), 91-99.

Morrison, A., \& O'Gorman, K. (2008). Hospitality studies and hospitality management: A symbiotic relationship. International Journal of Hospitality Management, 27(2), 214-221.

Morrison, A., \& O'Mahony, B. G. (2003). The liberation of hospitality management education. International Journal of Contemporary Hospitality Management, 15(1), 38-44.

Pang, L. W. L., Wong, S. C. K., \& Wong, N. C. M. (2013). School and hotel integration: Practices and experiences from stakeholders. Journal of Hospitality, Leisure, Sport \& Tourism Education, 13, 5-18.

Pizam, A., Okumus, F., \& Hutchinson, J. (2013). Forming a long-term industryuniversity partnership: The case of Rosen College of Hospitality Management. Worldwide Hospitality \& Tourism Themes, 5(3), 244-254.

Raybould, M., \& Wilkins, H. (2006). Generic skills for hospitality management: A comparative study of management expectations and student perceptions. Journal of Hospitality \& Tourism Management, 13, 177-188.

Rivera, M. A., \& Pizam, A. (2015). Advances in hospitality research: "From Rodney Dangerfield to Aretha Franklin". International Journal of Contemporary Hospitality Management, 27(3), 362-378.

Rivera, M. A., \& Upchurch, R. (2008). The role of research in the hospitality industry: A content analysis of the IJHM between 2000 and 2005. International Journal of Hospitality Management, 27(4), 632-640.

Roberts, E. (2009). Mind the gap: Aligning learning and graduate outcomes through industry partnerships. Journal of Hospitality \& Tourism Management, 16, 130138.

Robinson, R. N., Breakey, N. M., \& Craig-Smith, S. J. (2010). Food for thought: Investigating food and beverage curricular in Australian hospitality degree programs. Journal of Hospitality \& Tourism Education, 22(1), 32-42. 
Robinson, R. N., Kralj, A., Brenner, M. L., \& Lee, A. H. (2014). Reflective Practice in food and beverage education. Journal of Hospitality \& Tourism Education, 26(4), 166-177.

Ryan, C. (2015). Trends in hospitality management research: A personal reflection. International Journal of Contemporary Hospitality Management, 27(3), 340361.

Sana, F., Weston, T., \& Cepeda, N. J. (2013). Laptop multitasking hinders classroom learning for both users and nearby peers. Computers \& Education, 62, 24-31.

Sanders, D., \& LeClus, M. (2009). All wired up but not plugged in: An evaluation of tourism and leisure marketing students' expectations and experiences of lecture podcasting. Journal of Hospitality \& Tourism Management, 16, 94-101.

Shaw, S., \& Fairhurst, D. (2008). Engaging a new generation of graduates. Education+ Training, 50(5), 366-378.

Slattery, P. (2002). Finding the hospitality industry. Journal of Hospitality, Leisure, Sport \& Tourism Education, 1(1), 19-28.

Silvers, J. R., Bowdin, G. A., O'Toole, W. J., \& Nelson, K. B. (2005). Towards an international event management body of knowledge (EMBOK). Event Management, 9(4), 185-198.

Stierand, M., \& Zizka, L. (2015). Reflecting on hospitality management education through a practice lens. Quality Assurance in Education, 23(4), 353-363.

Terry, C. A., Mishra, P., \& Roseth, C. J. (2016). Preference for multitasking, technological dependency, student metacognition, \& pervasive technology use: An experimental intervention. Computers in Human Behavior, 65, 241251.

Thomas, D. R. (2006). A general inductive approach for analyzing qualitative evaluation data. American Journal of Evaluation, 27(2), 237-246.

Urry, J. (2007). Mobilities. Cambridge: Polity.

Wang, J., Ayres, H., \& Huyton, J. (2009). Job ready graduates: A tourism industry perspective. Journal of Hospitality \& Tourism Management, 16, 62-72

Weiler, A. (2005). Information-seeking behavior in generation Y students: Motivation, critical thinking, and learning theory. The Journal of Academic Librarianship, 31(1), 46-53.

Whitelaw, P. A., \& Wrathall, J. (2015). Developing practice oriented undergraduate courses in a quality framework: A case study: bachelor of event management. Quality Assurance in Education, 23(4), 395-409.

Wood, R. C. (2007). The future of food and beverage management research. Journal of Hospitality \& Tourism Management, 14, 6-16.

Wood, R. C. (2015). 'Folk' understandings of quality in UK higher hospitality education. Quality Assurance in Education, 23(4), 326-338.

Zwaal, W., \& Otting, H. (2015). Aligning principles and practice in problem-based hospitality management education. Journal of Hospitality, Leisure, Sport \& Tourism Education, 16, 22-29. 